https://doi.org/10.52058/2786-4952 -2021-4(4)-73-85

Блавт Оксана Зіновіївна професорка, докторка педагогічних наук, професорка кафедри фізичного виховання, Національний університет «Львівська політехніка», вул. Ст. Бандери, 12, м. Львів, 79013, тел.: (032) 276-43-80, e-mail: oksanablavt@ukr.net, https://orcid.org/0000-0001-5526-9339

Козіброда Лариса Володимирівна доцентка, докторка педагогічних наук, доцентка кафедри фізичного виховання, Національний університет «Львівська політехніка», вул. Ст. Бандери, 12, м. Львів, 79013, тел.: (032) 276-43-80, e-mail: lora.kozibroda@gmail.com, https://orcid.org/0000-0001-8232-425X

Рожко Олена Ігорівна викладачка кафедри фізичного виховання, Національний університет «Львівська політехніка», 79013, м. Львів, вул. Ст. Бандери, 12, тел.: (032) 276-43-80, e-mail: olena_baranyuk@ukr.net, https://orcid.org/0000-0001-7885-7846

\title{
ПЕДАГОГІЧНІ ОСНОВИ ФОРМУВАННЯ АДАПТАЦІЇ ДО ОСВІТНЬОГО СЕРЕДОВИЩА ЗАКЛАДІВ ВИЩОЇ ОСВІТИ У СТУДЕНТІВ 3 ОСОБЛИВИМИ ОСВІТНІМИ ПОТРЕБАМИ
}

Анотація. Стаття присвячений актуальній проблемі адаптації студентів 3 особливими освітніми потребами у навчальному процесі закладу вищої освіти. Досліджено потенціал фізичного виховання у напрямі превенції наявних негативних тенденцій у фізичному розвитку і здоров'ї студентів з особливими освітніми потребами у ході їхньої адаптації до умов навчання. Визначено, що інклюзивне фізичне виховання передбачає технологію й організацію діагностичних та оздоровчих засобів для студентів 3 особливими освітніми потребами. У результаті науково-пошукової роботи установлено, що формування безпечного та здорового освітнього середовища потребує модернізувати процес фізичного виховання студентів, використовуючи його можливості у забезпеченні повноцінної теперішньої й подальшої життєдіяльності таких студентів засобами інклюзивного фізичного виховання. Обгрунтовано, що це передбачає упровадження у навчальний процес технології організації інклюзивного фізичного виховання для студентів 3 студентів 3 особливими освітніми потребами. Для забезпечення зазначеного розроблено проект технології, складовими якого є: суб'єкти процесу, мета, функції, підходи, принципи, завдання, організація і зміст фізичної культури, контроль, очікуваний результат. Результати наукової розвідки сприяли виокремленню комплексу практичних заходів інклюзивного фізичного виховання, передбачених розробленою 
технологією задля створення оптимальних умов для забезпечення адаптації студентів з особливими освітніми потребами до освітнього середовища вищої школи на основі врахування широкого розмаїття їхніх індивідуальних особливостей і можливостей, детермінованих станом здоров'я, особливостями фізичного розвитку й специфіки освітніх потреб. Визначено, що ефективність практичної реалізація окреслених положень технології забезпечується обгрунтованими методичними основами фізичного виховання студентів 3 особливими освітніми потребами, спрямовані на задоволення індивідуальних освітніх потреб. Принципово новим для теорії та практики фізичного виховання студентів з особливими освітніми потребами є активізація педагогічного аспекту корекційного впливу. Очікуваний результат реалізації представленої педагогічні технології полягає досягненні позитивного ефекту адаптації студентів 3 особливими освітніми потребами до освітнього середовища закладу вищої освіти.

Ключові слова: студенти 3 особливими освітніми потребами, інклюзія, освітнє середовище, адаптація, фізичне виховання.

Blavt Oksana Zinoviivna Professor, Dr. (Pedagogic Sciences), Professor of the Department of Physical Education, Lviv Polytechnic National University, St. Banderi St., 12, Lviv, 79013, tel: (032) 276-43-80, e-mail: oksanablavt@ukr.net, https://orcid.org/0000-0001-5526-9339

Kozibroda Larysa Volodymyrivna Associate Professor, Dr. (Pedagogic Sciences), Associate Professor of the Department of Physical Education, Lviv Polytechnic National University, St. Banderi St., 12, Lviv, 79013, tel. (032) 276-43-80, e-mail: lora.kozibroda@gmail.com, https://orcid.org/0000-0001-8232-425X

Rozhko Olena Ihorivna Lecturer of the Department of Physical Education, Lviv Polytechnic National University, St. Banderi St., 12, Lviv, 79013, tel. (032) 276-43-80, e-mail: olena_baranyuk@ukr.net, https://orcid.org/0000-0001-7885-7846

\title{
PEDAGOGICAL FUNDAMENTALS OF FORMATION OF ADAPTATION TO THE EDUCATIONAL ENVIRONMENT OF HIGHER EDUCATION INSTITUTIONS IN STUDENTS WITH SPECIAL EDUCATIONAL NEEDS
}

\begin{abstract}
The article is devoted to the topical problem of adaptation of students with special educational needs in the educational process of higher education institutions. The potential of physical education in the direction of prevention of existing negative tendencies in physical development and health of students with special educational needs in the course of their adaptation to learning conditions is investigated. It is determined that inclusive physical education involves technology and
\end{abstract}


the organization of diagnostic and health tools for students with special educational needs. As a result of research work, it was found that the formation of a safe and healthy educational environment requires modernizing the process of physical education of students, using its capabilities to ensure the full current and future life of such students through inclusive physical education. It is substantiated that this involves the introduction into the educational process of the technology of organization of inclusive physical education for students from students with special educational needs. To ensure this, a technology project has been developed, the components of which are: the subjects of the process, purpose, functions, approaches, principles, objectives, organization, and content of physical culture, control, the expected result. The results of scientific research helped to identify a set of practical measures for inclusive physical education, provided by the developed technology to create optimal conditions for adaptation of students with special educational needs to the educational environment of higher education based on a wide variety of their individual characteristics and opportunities. physical development and the specifics of educational needs. It is determined that the effectiveness of the practical implementation of the outlined provisions of technology is provided by sound methodological foundations of physical education of students with special educational needs, aimed at meeting individual educational needs. Fundamentally new for the theory and practice of physical education of students with special educational needs is the activation of the pedagogical aspect of corrective action. The expected result of the implementation of the presented pedagogical technology is to achieve a positive effect of adaptation of students with special educational needs to the educational environment of higher education.

Keywords: students with special educational needs, inclusion, educational environment, adaptation, physical education.

Постановка проблеми. За останне десятиріччя 3 точки зору політики та практики, інклюзивна освіта завоювала позиції на національному рівні. Ініціатива ЮНЕСКО в документі Education 2030 розглядає інклюзивне навчання як процес забезпечення якісного навчання осіб 3 особливими освітніми потребами (ООП) являє собою важливий крок вперед, який визначає чіткий пріоритет у забезпеченні інклюзивності та справедливості на здобуття якісної освіти та створення усіх можливостей навчання для осіб із ООП [7].

Визнано беззаперечним [2, 9], що формування безпечного та здорового освітнього середовища сприятиме кращій реалізації інтелектуального, фізичного, соціального та емоційного розвитку студентів з ООП, їхнього потенціалу, а також матиме позитивний вплив на стан громадського здоров'я, економіки та демографії в цілому в Україні.

Студенти з ООП потребують такого стану освітнього середовища, в якому вони відчуватимуть фізичну, психологічну, інформаційну та соціальну безпеку, комфорт і благополуччя [3]. Зауважено [1], що концепція формування безпечного 
та здорового освітнього середовища як освітнього принципу, так і практичного застосування залишається одним із найскладніших завдань, пов'язаних з освітою. Сьогодні, коли кількість студентів з ООП невпинно зростає, проблема їхньої адаптації до загальноосвітнього простору є вкрай актуальною.

Аналіз останніх досліджень і публікацій. Існує безліч міжнародних посібників та ресурсів, які підтримують інклюзію в освіті (ЮНЕСКО 2015b, 2016, 2017; ЮНІСЕФ 2010). Питання інклюзивної освіти нині $є$ частиною освітнього дискурсу щодо виявлення суперечності у доступі студентів з ООП до здобуття якісної освіти.

Визначено [11], що в демократичному суспільстві освіта або є інклюзивною, або не є освітою. Еволюція наукових знань щодо інклюзії в освіту починаються iз Заяви ООН з прав людини 1948 р., які донині є актуальними, заснованими на правах людини [9], особливою увагою до студентів з ООП та передбачають трансформацію освітніх систем. Переходячи до концептуалізації інклюзії як процесу трансформації, ідея полягає в тому, щоб мінімілізувати процеси виключення з освіти осіб з ООП (ЮНЕСКО 2009).

Наявні погляди щодо цього питання можна презентувати так, що реалізація гуманістичних принципів у ставленні до студентів з ООП вимагає нової моделі освітнього середовища, яке відповідало би потребам і можливостям кожного студента [1, 4]. Визначено [2, 9], що стратегія інклюзивної освіти базується на наданні якісних освітніх послуг та адаптації освітнього середовища закладів вищої освіти (ЗВО) до потреб студентів з ООП.

У цьому аспекті у наукових джерелах [5, 10] особлива увага приділяється можливостям фізичного виховання в процесі сприяння адаптації студентів з ООП до умов навчання у ЗВО. Останнє, на думку спеціалістів є найбільш дійовим засобом забезпечення адаптації студентів з ООП до умов навчання $[11,12]$. Доведено [13], що розвиток адаптації студентів з ООП, які мають вікові та гендерні особливості, має забезпечити раціональна організація процесу фізичного виховання у ЗВО.

У наукових джерелах [4, 11] акцентовано увагу на впливі занять із фізичного виховання на рухову і психічну сфери студентів з ООП так, аби запобігти утворенню неадекватної адаптації у ЗВО. Остання [3] може стати чинником зниження рівня функціонування окремих систем, напруження регуляторних механізмів, втрати функціональних ресурсів; наслідком яких $\epsilon$ погіршення загального стану здоров'я студентів з ООП. Виявлено [5], що у процесі фізичного виховання здійснюється формування й удосконалення моторних функцій, які порушені внаслідок патологічного процесу, відбувається компенсація основного дефекту та корекція вторинних порушень, що виникли під час захворювання.

Досліджено [6], що зміна освітнього середовища під час навчання зумовлює серйозний стрес, який негативно позначається на здоров’і, у підсумку - на загальному стані студентів з ООП. Існують думки $[2,10]$, що створення у 3 ВО безпечного i здорового освітнього середовища для студентів з ООП вимагає 
вирішення низки проблем, зокрема, пов'язаних із непопулярністю занять із фізичного виховання, малорухливим способом життя, а також загалом несистемним підходом до формування культури здорового способу життя у суспільстві. Науковці єдині у думці $[5,13]$, що визначну роль у процесі адаптації до освітнього середовища належить дисципліні «Фізичне виховання», як засобу набуття навичок здорового способу життя студентів 3 ООП та створення можливості отримання певного запасу знань та умінь їхнього застосування.

Іншими словами, провідна роль фізичного виховання полягає у превенції незадовільного стану здоров'я студентів, як наслідку пристосування до процесу навчання у ЗВО і подальшої відповідної корекції цього процесу адекватними педагогічними засобами й методами [4]. У цьому контексті оптимальна організація занять із фізичного виховання задля формування адаптації студентів з ООП до освітнього середовища ЗВО є актуальним для вирішення проблематики їхнього здоров'язбереження.

Мета статті - виявлення та обгрунтування педагогічних основ формування адаптації до освітнього середовища $3 \mathrm{BO}$ у студентів 3 ООП засобами інклюзивного фізичного виховання.

Методи дослідження: теоретичний аналіз, систематизація, порівняння різних поглядів на досліджувану проблему, узагальнення даних науковометодичної та спеціальної літератури.

Виклад основного матеріалу. Нині термін «інклюзивна освіта» набув різноманітних значень і $є$ предметом дискусії наукових розвідок. У цілому, інклюзія передбачає створення освітнього середовища, яке відповідало би запитам і можливостям кожного здобувача освітніх послуг [1]. У найбільш узагальненому понятті, інклюзивна освіта представлена на кшталт системи гарантованих державою освітніх послуг, заснованих на принципах недискримінації, поваги до людського різноманіття, ефективного залучення до навчально-виховного процесу всіх його учасників [5]. Стратегія інклюзивної освіти зокрема у ЗВО має в своїй основі надання якісних освітніх послуг та адаптації освітнього середовища до потреб студентів [6].

Сьогоденна трансформація педагогічної парадигми сучасної вищої школи від авторитарної до особистісно орієнтованої моделі освіти, передбачає ліквідацію ізольованості у процесі здобуття вищої освіти будь-яких категорій студентів. Вважаймо, що формування безпечного та здорового освітнього середовища потребує модернізувати процес фізичного виховання студентів 3 ООП, використовуючи потенціал наявного міцного зв’язку їх фізичного та соціального, інтелектуального, духовного розвитку, а відтак - можливостей цього процесу у забезпеченні повноцінної теперішньої й подальшої життєдіяльності таких студентів.

Ми узгоджуємо наше дослідження у тому, що перспективним напрямом розв'язання означеної наукової проблеми $є$ врахування засадничих положень інклюзивної педагогіки. Таке твердження обгрунтовано тим, що первинна 
соціальна інклюзія, як одна 3 iі складових, спрямована на створення умов із попередження негативного впливу на студента 3 ООП комплексу зовнішніх чинників у процесі їхньої адаптації до освітнього середовища (навчальне навантаження, колектив тощо), підвищення опірності організму до такого впливу, запобігання найпоширенішим захворюванням, упередження негативної тенденції у стані їхного здоров’я.

Ми підтримуємо наукові підходи [10, 13], щодо необхідності інклюзивного фізичного виховання студентів з ООП, яка зумовлена потребою виховання відповідального ставлення до власного здоров'я, здорового способу життя; формування знань і навичок фізичної культури в таких студентів; забезпечення їхнього повноцінного фізичного розвитку; фізичного, духовного та психічного загартування; формування потреби у безпечній поведінці, протидії та запобігання негативним звичкам, профілактиці захворювань; створення умов для активного відпочинку студентів з ООП в умовах навчання у ЗВО.

Важливо врахувати, що адаптація до умов навчання у ЗВО пов'язана, перш за все, з різкою зміною соціального стану особистості. У доробку психологопедагогічних наукових розвідок існує значна кількість трактувань дефініції «адаптація». Аналізуючи спеціальну літературу у напрямі виокремлення характеристик терміну в аспекті нашої наукової розвідки, вважаймо, що адаптація студентів 3 ООП - це процес пристосування, результатом якого $\epsilon$ встановлення взаємної відповідності між потребами студентів 3 ООП та вимогами навчання у ЗВО.

Надалі ми узгоджуємо наше дослідження у напрямі, що інклюзивне фізичне виховання забезпечує спеціальну організацію освітнього середовища 3ВО, спрямованого на упередження наявних негативних тенденцій у стані здоров ї студентів 3 ООП, зумовленим процесом адаптації. В основі цього процесу положення теорії адаптації [5]. Останні використовуються для вирішення прикладних завдань, пов'язаних 3 контролем за станом організму в неадекватних умовах середовища. 3 нашого погляду це повинно реалізовуватись цілеспрямованим впливом засобами фізичного виховання з урахуванням індивідуальних особливостей фізичного стану студентів з ООП та прояву ії компонентів.

Отож, надалі у нашій науковій розвідці позиціонуємо адаптацію у якості стратегії, яка допомагає студентам 3 ООП в досягненні індивідуального максимально високого рівня засвоєння тих самих обсягів знань, що забезпечує повноцінне, продуктивну діяльність у вищій школі. Своєю чергою, інклюзивне фізичне виховання - це керована діяльність, яка забезпечує теоретичну i практичну реалізацію фізичного виховання інклюзивного характеру. Як свідчать дані [8], гармонійний розвиток всіх функціональних систем організму в процесі фізичного виховання забезпечує позитивну динаміку адаптаційних можливостей організму і зміцнення індивідуального здоров'я.

На переконання дослідників, дефініція «інклюзивне фізичне виховання» 3 одного боку розуміється у якості спеціалізованого педагогічного процесу 
цілеспрямованого впливу засобами фізичного виховання на поліпшення фізичного стану [13]. 3 іншого[5], як стратегія профілактики хронічних соматичних захворювань. С очевидним, що незважаючи на розбіжності у поглядах дослідників щодо інклюзивного фізичного виховання, то воно передбачає технологію й організацію діагностичних та оздоровчих засобів для студентів з ООП.

Втім, вважаймо, що інклюзивне фізичне виховання у ЗВО це вкрай складна й тривала педагогічна інновація, особливо з огляду, що ми розглядаємо цей детермінований процес для студентів з ООП. Як самостійний спеціалізований вид педагогічного процесу, він має свою мету, принципи, зміст, форми і методи та використовує елементи фізкультурно-оздоровчої роботи. Першочергового значення у його реалізації для студентів з ООП набувають нові педагогічні технології, методи і засоби навчання, які мають сформувати суб'єкта реалізації освітнього процесу з високим рівнем соматичного здоров'я.

У педагогічному процесі фізичного виховання студентів з ООП насамперед потрібно виходити 3 того, що саме фізичне виховання володіє значним потенціалом розвитку, повноцінна реалізація якого залежить від адекватності побудови навчально-виховного процесу [1]. Отож, грунтуючись на вказаному, виокремлено складові технології інклюзивного фізичного виховання, серед котрих: суб'єкти процесу (студенти з ООП), мета, функції, підходи, принципи, завдання, організація і зміст фізичного виховання, контроль, очікуваний результат.

Сформулюймо мету інклюзивного фізичного виховання у формуванні адаптації до освітнього середовища у студентів з ООП, яка на наше переконання полягає у сформованості імунітету до негативних впливів зміни освітнього середовища на основі зміцнення здоров'я одночасно з розв'язанням корекційних завдань, досягненням індивідуально максимального оздоровчого і прикладних ефектів при впливі фізичного виховання на їх рухову активність для забезпечення повноцінного, продуктивного життя і діяльності у вищій школі. Тобто мета розглядається поліаспектно й вимагає інтеграції низки спеціальних корекційних задач, що мають самостійне значення, але тісно взаємопов'язаних. Реалізація цієї мети забезпечується обгрунтованими методичними основами розвитку адаптації студентів з ООП в процесі фізичного виховання.

У цілому, успішність адаптаційного процесу до освітнього середовища у студентів з ООП у процесі фізичного виховання зумовлюється раціональною організацією методичного супроводу, спрямованого на зміцнення індивідуального здоров'я учасників педагогічного процесу, 3 урахуванням індивідуальних особливостей адаптації до фізичних навантажень, поетапним застосуванням методик комплексної оцінки та контролю. На нашу переконання, зміст цього процесу значною мірою залежить від урахування індивідуальнотипологічних особливостей студентів з ООП. Причому всі заходи мають бути попереджуючого, випереджуючого, запобіжного характеру, тобто спиратись на 
Журнал«Герспективитаінновації науки»

(Серія«Гедагогіка», Серія«Гцихологія», Серія«Медицинв»

№4(4) 2021

положення превентивної педагогіки [8].

Отож, узагальненням досвіду систематизуємо основні функції інклюзивного фізичного виховання, вирішення яких забезпечить ефективність формування адаптації до освітнього середовища у студентів з ООП:

-організаційно-методична: забезпечення раціональної побудови процесу фізичного виховання, педагогічно зорієнтованого на вироблення стійкості до негативних впливів процесів адаптації;

- профілактиктична: комплексний психолого-педагогічний та медикобіологічний супровід процесу фізичного виховання задля визначення чинників порушення і зриву механізмів адаптації та пошук здоров’язабезпечувальних методик;

- просвітницька: стимулювання студентів з ООП до здорового способу життя, сприяння валеологізації навчально-виховного процесу, навчання охорони власного життя і здоров'я;

- корекційна: забезпечення компенсації основного дефекту й корекції вторинних порушень,обумовлених основним захворюванням, використання оптимальної коригувальної допомоги;

- освітньо-консультативна передбачає використання сучасних технологій надання оптимальної освітньої, консультативної інформації студентам з ООП щодо максимально можливого використання засобів фізичного виховання;

- розвивальна: реалізується у покращаннї психофізичного стану студентів.

Відтак, дієве втілення виокремлених функцій фізичного виховання студентів 3 ООП забезпечено вирішенням комплексу завдань як заздалегідь визначених досягнень, якими є:

-оздоровчі: забезпечення гармонійного усебічного фізичного розвитку студентів з ООП, їхнього саморозвитку;

- корекційно-розвивальні: передбачає поглиблену роботу з корекції фізичних функцій, зміцнення працездатності, забезпечення розвитку всіх фізичних якостей;

- виховні: спрямованість на досягнення цілей та завдань фізичного виховання у формуванні навичок систематичних занять 3 використанням усіх можливих форм $\mathrm{i}$ видів фізичної активності;

- контролювальні: забезпечення ефективного зворотного зв'язку у процесі фізичного виховання; організація змістового цілеспрямованого впливу контролю.

На основі здійсненого теоретичного й системного аналізу проблеми визначено педагогічні умови технології формування адаптації до освітнього середовища у студентів 3 ООП засобами інклюзивного фізичного виховання:

- створення сприятливих умов освітнього середовища для забезпечення розвитку адаптаційних можливостей студентів 3 ООП в процесі фізичного виховання;

- оздоровчий зміст фізичного виховання студентів з ООП;

- модернізація методичних основ фізичного виховання студентів з ООП;

- науково-обгрунтований вибір методик визначення раціональних фізичних навантажень в процесі фізичного виховання; 
- забезпечення перманентних контролю вальних процедур в процесі фізичного виховання.

В основі розроблення педагогічної технології інклюзивного фізичного виховання, що забезпечують реалізацію формування адаптації до освітнього середовища у студентів з ООП, слід використати системний, діяльнісний, компетентнісний та особистісний підходи 3 домінантністю корекційнорозвивального характеру, грунтуючись на основних положеннях інклюзивного фізичного виховання. При цьому, слід забезпечити максимальне зорієнтовання на засади міждисциплінарного підходу та міждисциплінарних зв'язків, як першооснов реалізації педагогічної технології інклюзивного фізичного виховання студентів з ООП.

Основними принципами розроблення змістової складової педагогічної технології інклюзивного фізичного виховання, що забезпечують реалізацію формування адаптації до освітнього середовища у студентів з ООП, вважаймо має бути принцип мінімальних та максимальних досягнень розвитку; принцип індивідуалізації розвитку; принципи складності, первинної структури дефекту; диференціації за принципом урахування відхилень у стані здоров'я; принципи доступності та достатності, неперервності та практичної цілеспрямованості, гуманізації і демократизації, синкретичності, єдності діагностики і корекції, комплексності методів психологічного впливу.

Реалізація педагогічної технології інклюзивного фізичного виховання, що забезпечує формування адаптації до освітнього середовища у студентів з ООП, на нашу думку, вимагає забезпечення: комплексного підходу до гармонійного формування всіх складових здоров'я; удосконалення фізичної та психологічної підготовки до активного життя і професійної діяльності на вищевикладених принципах; використання різноманітних форм рухової активності та інших засобів фізичного удосконалення.

Серед основних форм фізичного удосконалення необхідне використання поряд із основними заняттями із фізичного виховання, інтегровані: малі форми. Серед котрих: ранкова гімнастика, комплекс вправ після сну, прогулянки першої i другої половин дня, рухлива хвилинка, рухлива пауза, самостійна рухова діяльність; масові оздоровчі форми : туризм, день здоров’я, спортивно-ігрові свята тощо.

Зазначимо, що однією 3 найдоцільніших форм комплексної реалізації фізичного виховання студентів з ООП в умовах ЗВО є позааудиторні заняття. Такі форми занять студентів з ООП вимагають ретельного дослідження. Разом 3 тим організаційні можливості позааудиторних занять сприяють соціальносередовишній адаптації студентів з ООП на основі зміцнення фізичного здоров'я, розвитку морально-вольової підготовленості та формування творчого потенціалу.

Поділяємо думку практиків [2, 3], що використанням вище перелічених форм фізичного виховання студентів з ООП й інших індивідуальних методів 
впливу створює оздоровчий простір у ЗВО, яка сприяє адаптації до освітнього середовища у студентів з ООП. Принципово новим для теорії та практики фізичного виховання студентів з ООП $\epsilon$ активізація педагогічного аспекту корекційного впливу.

Щоб освітній процес у зазначеному контексті відповідав вимогам корекційного впливу, який інтегрується із дидактичним, та сприяв зміцненню здоров’я студентів з ООП, необхідне створення комфортних умов для засвоєння програмного матеріалу. Корекційний вплив передбачає створення умов для подолання психофізичних проблем на основі врахування єдності біологічних, фізичних, психологічних і соціальних особливостей стану здоров'я студентів 3 ООП. У цілому все це складає основу для ефективної організації фізичного виховання задля створення чинників, що сприяють адаптації до освітнього середовища у студентів з ООП. Дидактичний вплив вимагає створення усіх належних умов для підтримки і бажання бути здоровим, а також підготовку до використання вмінь і навичок щодо зміцнення власного здоров'я у студентів 3 ООП.

Очікуваний результат реалізації представленої педагогічні технології полягає досягненні позитивного ефекту адаптації студентів з ООП до освітнього середовища ЗВО. Зазначимо, що такий процес характеризується складністю, різнобічністю та динамічністю. Показниками i результатом позитивного розвитку адаптації є такі чинники: $є$ рівень здоров'я студентів з ООП, однією із складових якого є фізичний стан, який має в своїй основі: фізичний розвиток, фізична підготовленість, фізична працездатність, функціональні резерви, а саме біологічні і психічні, фізіологічні й біохімічні.

Висновки. Забезпечення справедливої якісної освіти та сприяння всім можливостям навчання передбачає організацію інклюзивного освітнього середовища на рівні 3 ВО задля підготовки студентів 3 ООП як майбутніх фахівців на основі цілеспрямованого формування професійних знань, умінь та навичок. Провідною місією вищої школи $\epsilon$ створення умов, що сприяють ефективному навчанню студентів з ООП як процесу виховання інтелектуальної еліти суспільства. Світові тенденції розвитку освітньої системи передбачають адаптацію освітнього середовища до потреб усіх учасників процесу здобуття вищої освіти.

Розв'язання проблеми формування адаптації до освітнього середовища у студентів з ООП передовсім передбачає превенцію незадовільного стану здоров'я студентів, як наслідку пристосування до процесу навчання у ЗВО i подальшої відповідної корекції цього процесу. Використовуючи потенціал наявного міцного зв'язку фізичного, соціального, інтелектуального та духовного розвитку, а відтак забезпечення повноцінної теперішньої й подальшої життєдіяльності студентів 3 ООП, розширено ідеї застосування засобів інклюзивного фізичного виховання як інструменту формування їхньої адаптації до освітнього середовища ЗВО. Останнє передбачає ефективну організацію 
фізичного виховання студентів 3 ООП задля потреби виховання у них відповідального ставлення до власного здоров'я, здорового способу життя; формування знань і навичок фізичної культури; забезпечення повноцінного фізичного розвитку; фізичного, духовного та психічного загартування; формування потреби у безпечній поведінці, протидії та запобігання негативним звичкам, профілактики захворювань; створення умов для активного відпочинку в умовах навчання у ЗВО.

Зміст і завдання інклюзивного фізичного виховання реалізуються у педагогічні технології 3 визначенням методів і засобів фізичного виховання, які мають сформувати суб'єкта реалізації освітнього процесу з високим рівнем соматичного здоров'я. Виконання зазначених завдань повинно сприяти досягненню істотного рівня адаптації до освітнього середовища ЗВО на основі фізичної досконалості, детермінованого мотиваційно-цінностними орієнтаціями здорового способу життя, набутих у результаті фізичного виховання, та інтегрованих у фізкультурноспортивній діяльності та психофізичному здоров’ї студентів з ООП.

\section{Jimepamypa:}

1. Бондар К. М. Теорія і практика інклюзивної освіти. Проект «Підтримка інклюзивної освіти у м. Кривий Ріг». Видавництво ФО-П Чернявський Д.О., 2019, 170 с.

2. Гладиш М. О. Наукові підходи до проблеми адаптації студентів 3 особливими освітніми потребами в умовах закладу вищої освіти. Педагогіка формування творчоі особистості у вищій $i$ загальноосвітній школах, $2019 . \quad 63(2)$, С. 55-58. https://doi.org/:10.32840/1992-5786.2019.63-2.11.

3. Маляр Н. С., Маляр Е. І., Огнистий А. В., Огниста К. М. Реалізація експериментальної методики превентивного фізичного виховання у закладах вищої освіти. Науковий часопис Національного педагогічного університету імені М. П. Драгоманова. Серія 15. Науковопедагогічні проблеми фізичної культури (фізична культура і спорт), 2020, 2(122), С. 106-112. https://doi.org/10.31392/NPU-nc.series15.2020.2(122).21

4. Міщик, Л. І. Інтеграція студентів різної інвалідності в освіту. Вісник Запорізького національного університету, 2007, № 1, С 131-136.

5. Мукан Н., Козіброда Л. Значення фізичного виховання і спорту у соціалізації дітей 3 особливими потребами. Молодь і ринок, 2021, 1(187), С. 27-32. https://doi.org/10.24919/23084634.2021.228269

6. Сакалюк О. О., Александрова С. О. Розвиток освітнього середовища як технологія управління навчальним закладом в умовах інклюзії. Вісник Черкаського університет. Серія: Педагогічні науки, 2016, №13, С. 22-27.

7. Талдонова Л. О. Інклюзивне освітнє середовище. Теорія і практика сучасної психології, 2018, № 6, С. 97-101.

8. Шевців 3. М. Основи інклюзивної педагогіки. К.:Щентр учбової літератури», 2016, 248 с.

9. Удич Ю 3. Формування предметно-просторового середовища інклюзивного освітнього середовища. Педагогічна преса, 2018, №1(85), С. 85-96.

10. Escartí A., Gutiérrez M. Influence of the motivational climate in physical education on the intention to practice physical activity or sport. European Journal of Sport Science, 2010, № 9, PP. 112. https://doi.org/10.1080/17461390100071406.

11. Morley D., Bailey R., Tan J., Cooke B. Inclusive physical education: teachers' views of including pupils with special educational needs and/or disabilities in physical education. Eur. Phys. Educ. Rev, 2005, №11, PP. 84-107. https://doi.org/:10.1177/1356336X05049826. 
12. Page A., Anderson J., Charteris J. Including students with disabilities in innovative learning environments: a model for inclusive practices, International Journal of Inclusive Education, 2021, 4. https://doi.org/10.1080/13603116.2021.1916105

13. Tant M., Watelain, E. Forty years later, a systematic literature review on inclusion in physical education (1975-2015): a teacher perspective. Educ. Res. Rev, 2016, № 19. PP. 1-17. https://doi.org/: 10.1016/j.edurev.2016.04.002.

\section{References:}

1. Bondar, K. M. (2019). Teoriia i praktyka inkliuzyvnoi osvity. Proekt «Pidtrymka inkliuzyvnoi osvity $u$ m. Kryvyi Rih» [Theory and practice of inclusive education. Project "Support for inclusive education in Kryvyi Rih"]. Vydavnytstvo FO-P Cherniavskyi D.O., 170. [in Ukrainian].

2. Hladysh, M. O. (2019). Naukovi pidkhody do problemy adaptatsii studentiv z osoblyvymy osvitnimy potrebamy $\mathrm{v}$ umovakh zakladu vyshchoi osvity [Scientific approaches to the problem of adaptation of students with special educational needs in the conditions of higher education institution]. Pedahohika formuvannia tvorchoi osobystosti u vyshchii $i$ zahalnoosvitnii shkolakh, 63(2), 55-58. https://doi.org/:10.32840/1992-5786.2019.63-2.11.

3. Maliar, N. S., Maliar, E. I., Ohnystyi, A. V., Ohnysta, K. M. (2020). Realizatsiia eksperymentalnoi metodyky preventyvnoho fizychnoho vykhovannia u zakladakh vyshchoi osvity [Implementation of experimental methods of preventive physical education in higher education institutions]. Naukovyi chasopys Natsionalnoho pedahohichnoho universytetu imeni M. P. Drahomanova. Seriia 15. Naukovo-pedahohichni problemy fizychnoi kultury (fizychna kultura i sport), 2(122), 106-112. https://doi.org/10.31392/NPUnc.series15.2020.2(122).21[in Ukrainian].

4. Mishhy`k, L. I. (2007). Integraciya studentiv riznoyi invalidnosti v osvitu [Integration of students with different disabilities into education]. Visny`k Zaporiz`kogo nacional `nogo universy`tetu, 1, 131-136. [in Ukrainian]

5. Mukan N., \& Kozibroda L. (2021). Znachennia fizychnoho vykhovannia i sportu u sotsializatsii diteiz osoblyvymy potrebamy [The importance of physical education and sports in the socialization of children with special needs] Molod $i$ rynok, 1(187), 27-32. https://doi.org/10.24919/2308-4634.2021.228269 [in Ukrainian].

6. Sakalyuk, O. O., \& Aleksandrova, S. O. (2016). Rozvy`tok osvitn`ogo seredovy`shha yak texnologiya upravlinnya navchal`ny`m zakladom v umovax inklyuzii. [Development of educational environment as a technology of school management in the conditions of inclusion]. Visny`k Cherkas `kogo universy`tet. Seriya: Pedagogichni nauky,13, 22-27. [in Ukrainian]

7. Taldonova, L. O. (2018). Inkliuzyvne osvitnie seredovyshche. Teoriia i praktyka suchasnoi psykholohii [Inclusive educational environment. Theory and practice of modern psychology], 6, 97101. [in Ukrainian].

8. Shevtsiv, Z. M. (2016). Osnovy inkliuzyvnoi pedahohiky [Fundamentals of inclusive pedagogy]. K.:«Tsentr uchbovoi literatury», 248 c. [in Ukrainian].

9. Udy`ch, Yu Z. (2018). Formuvannya predmetno-prostorovogo seredovy`shha inklyuzy`vnogo osvitn`ogo seredovy`shha [Formation of subject-spatial environment of inclusive educational environment]. Pedagogichna presa, 1(85), 85-96. [in Ukrainian]

10. Escartí, A. \& Gutiérrez, M. (2010). Influence of the motivational climate in physical education on the intention to practice physical activity or sport. European Journal of Sport Science, 9, 1-12. https://doi.org/10.1080/17461390100071406.

11. Morley, D., Bailey, R., Tan, J., \& Cooke, B. (2005). Inclusive physical education: teachers' views of including pupils with special educational needs and/or disabilities in physical education. Eur. Phys. Educ. Rev, 11, 84-107. https://doi.org/:10.1177/1356336X05049826. 
12. Page, A., Anderson, J. \& Charteris, J. (2021). Including students with disabilities in innovative learning environments: a model for inclusive practices, International Journal of Inclusive Education https://doi.org/10.1080/13603116.2021.1916105

13. Tant, M., \& Watelain, E. (2016). Forty years later, a systematic literature review on inclusion in physical education (1975-2015): a teacher perspective. Educ. Res. Rev, 19, 1-17. https://doi.org/: 10.1016/j.edurev.2016.04.002. 